DOI: $10.4274 /$ jarem.galenos.2021.3853

J Acad Res Med 2021;11(1):75-80

\title{
Does Hair Strand Cause Failure of Sterilization? A Controlled Experimental Study
}

\author{
(ㄱ) Nurgül Arpag1, (1) Süheyla Yazıcıoğlu2, (1) Ayşenur Curabeyoğlu2, (10) Hamdiye Banu Katran1, (1) Sevgi Gür1, \\ (1) Anıl Demiröz 3 , (i) Fatma Altınkılıç4 \\ ${ }^{1}$ istanbul University-Cerrahpaşa, Florence Nightingale Faculty of Nursing, Institute of Graduate Studies, İstanbul, Turkey \\ ${ }^{2}$ istanbul Yeni Yüzyıl University, Health Care Vocational School, Medical Laboratory Techniques, İstanbul, Turkey \\ ${ }^{3}$ istanbul University-Cerrahpaşa, Cerrahpaşa Faculty of Medicine, Department of Plastic, Reconstructive and Aesthetic Surgery, İstanbul, Turkey \\ ${ }^{4}$ Yeni Yüzyıl University, Gaziosmanpaşa Hospital, Clinic of Operating Room, İstanbul, Turkey
}

Cite this article as: Arpag N, Yazıcıoğlu S, Curabeyoğlu A, Katran HB, Gür S, Demiröz A, Altınkılıç F. Does Hair Strand Cause Failure of Sterilization? A Controlled Experimental Study. J Acad Res Med 2021;11(1):75-80

\begin{abstract}
Objective: Besides the standard applications of surgical aseptic techniques, it is known that different teams display different approaches in the presence of a hair strand in sterile packs. Few of the teams prefer not to use the instruments and postpone the surgery, whereas others may decide to remove the hair and the instruments in contact and continue using the remaining part. Evidence is required to determine a standard approach in such practices, which leads to negative consequences.

Methods: Overall, 108 surgical clamps were sterilised using autoclave $(n=36)$, hydrogen peroxide $(n=36)$, and ethylene oxide $(n=36)$. One third of the instruments in each group were packed along with a free hair strand, another third with a strangulated hair strand, and the last third were packed alone as the control group. Microbiological specimens of the instruments were collected with swabs. Hair samples were inoculated on thioglycolate broth. Growth was evaluated after 24 and 48 hours.

Results: No growth was observed among the groups after 24 and 48 hours. Thus, all the instruments were considered sterile.

Conclusion: Hair was shown to have no significant effect as a biological burden on bacterial contamination risk.

Keywords: Infection, sterilization, disinfection, hair, asepsis
\end{abstract}

\section{INTRODUCTION}

Despite advances in diagnosis, treatment and surgical intervention methods in surgical diseases, surgical infections remain to be the most common surgical complication. In addition to preoperative patient preparation, full and complete application of sterilization and surgical aseptic technical principles is the most significant basic element in preventing surgical infections (1-4).
Creating and maintaining the surgical aseptic area throughout the procedure is crucial in patient safety in the operating room. Surgical instruments to be used in the operation should be decontaminated, washed and disinfected with the correct methods before sterilization. In the presence of macroscopic remnants or inappropriate results, the processes should be repeated. Packaging should be done with appropriate materials. Appropriate sterilization, transfer and storage of the

ORCID IDs of the authors: N.A. 0000-0002-7774-3844; S.Y. 0000-0003-1682-0559; A.C. 0000-0002-5599-2356; H.B.K. 0000-0001-5095-6316; S.G. 0000-0002-6925-3351; A.D. 0000-0001-6182-6939; F.A. 0000-0002-4072-8333.

Corresponding Author/Sorumlu Yazar: Hamdiye Banu Katran, E-mail: banu-katran@hotmail.com
Received Date/Geliş Tarihi: 13.10.2020 Accepted Date/Kabul Tarihi: 02.03 .2021

(C) Copyright 2021 by University of Health Sciences Turkey, Gaziosmanpaşa Training and Research Hospital. Available on-line at www.jarem.org 
sterile materials should be used to provide the sterilization cycle $(1,5-7)$.

Following the arrival of the surgical instruments and equipment to the operation room after a complete application of the sterilization cycle, it is crucial for the scrub and circulating nurse to create and maintain the aseptic area according to patient safety practices (8). Besides standard applications of surgical aseptic techniques, different teams exhibit different approaches in the presence of a hair strand in sterile packs, sets or bundles, a problem faced primarily by operating room nurses.

This situation might be a result of the incompatibility of working conditions during the packaging stage; however, the most significant issue to be sure about before making a decision is to determine whether the hair falls after opening of the package or not. In case of doubt, in accordance with the surgical aseptic technical standards, any suspicious occurrence should be considered as an impairment of sterilization $(9,10)$.

Few teams prefer not to use the instruments, sets or bundles and even postpone cases that have no set alternative even though they know the hair was placed in the packaging stage. Some other teams may choose to continue using the set after removal of the hair strand. In cases with no set alternatives (e.g. the orthopaedic kit supplied by the company), evidence is required in determining a standard approach in such practices, which leads to significant consequences with adverse effects on the patient, the workflows of the teams and corporate functioning. This study aimed to evaluate the effect of a hair strand on sterilization of surgical instruments sterilised with autoclave, hydrogen peroxide and ethylene oxide techniques.

\section{METHODS}

The experimental protocol for the study was approved by the İstanbul Yeni Yüzyıl University, Local Ethics Committee (approval number: 2020/06-453, approval date: 08.06.2020). This nonrandomised post-test-controlled study was designed to provide evidence in the case of presence of a hair strand in packages sterilised in autoclave, hydrogen peroxide and ethylene oxide. There was no contact with the patient within the scope of the study; hence, patient consent was waived.

\section{Cleaning of Surgical Instruments}

Overall, 108 surgical instruments (surgical clamps) were cleaned by washing and rinsing at $60{ }^{\circ} \mathrm{C}$ (LK/OX-500, Laoken Medical Technology Co., Ltd.). No additional treatment such as prewash, drying, or disinfection was applied.

\section{Classifying of Surgical Instruments Into Groups and Subgroups}

The instruments were divided into three groups ( $n=36$ each) and were to be sterilised using autoclave, hydrogen peroxide and ethylene oxide. Each group was divided into three subgroups ( $n=12$ each). Twelve instruments in each group were packed separately to create the control groups. Twelve instruments in each group were packed with a free hair strand to create experimental group 1, and 12 in each group were packed with a strangulated hair strand on them to create experimental group 2. All packs were assigned a descriptive number (Figure 1).

\section{Packing of Surgical Instruments}

All instruments were packed separately in double layers, using paper-film packaging (Sterintech, SP Medikal Co., Ltd.) of 75×250 $\mathrm{mm}$ in size as the inner layer and $100 \times 300 \mathrm{~mm}$ in size as the outer layer. Chemical indicators suitable for sterilization method were placed on the first layer of the packages (Attest Rapid Readout 1292, 3M; Attest Rapid Readout 1295, 3M; Attest 1264, 3M); all packages were sealed using the same device at $80^{\circ} \mathrm{C}$ (Rebi Evo, Gandus Saldatrici Srl).

\section{Sterilisation of Surgical Instruments}

Thirty-six of the packs were sterilised in autoclave at $134^{\circ} \mathrm{C}$ and press steamed for 7 minutes (V-1263, Steris), 36 in hydrogen peroxide at $55^{\circ} \mathrm{C}$ for 70 minutes (HRF3000, Teknomar) and 36 in ethylene oxide at $55^{\circ} \mathrm{C}$ for 180 minutes (ETO C 1445, Teknomar), all at the same stage and without any delay. Device performances were followed by daily rapid test biological markers and weekly applied air leak test packs. All instruments were unpacked 12 hours after sterilization in sterile conditions.

\section{Microbiological Cultivation}

The instruments were unpacked one by one in sterile conditions placed close to the spirit stove. Swab samples of the instruments were taken using cotton swab sticks dampened with saline solution. Microbiological swab cultivation was performed on $5 \%$ sheep blood agar (GBL/Gül Biology Laboratory Industry and Trade Limited Company, rrf. no: 0854), which is suitable for the growth of several microorganisms with rich nutrient content and ensures that hemolysis is evident (Figure 2). Incubation was performed for 24-48 hours at $37^{\circ} \mathrm{C}$.

Free or strangulated hair samples were plated in the thioglycolate broth (GBL/Gül Biology Laboratory Industry and Trade Limited

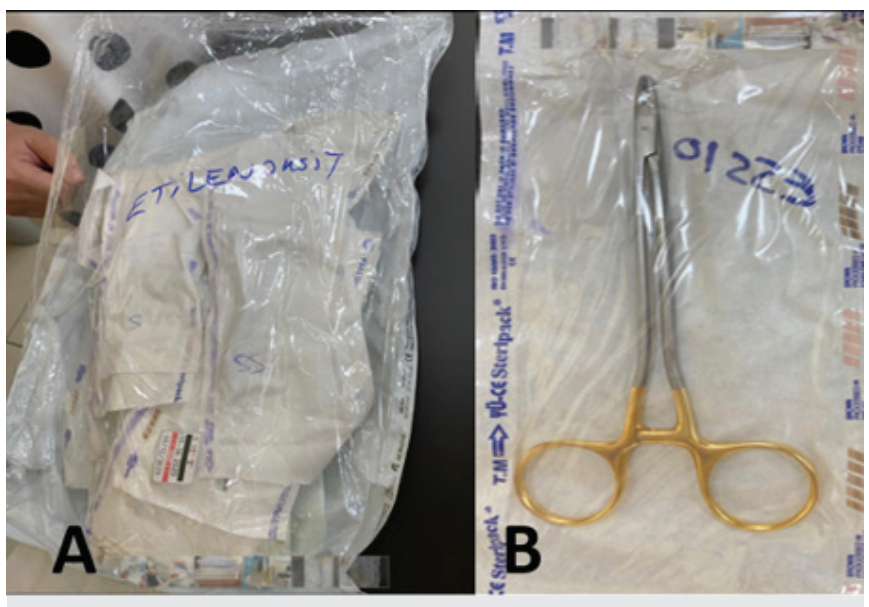

Figure 1. A) Stack of surgical instruments sterilised in ethylene oxide. B) A pack of instrument with the descriptive number 


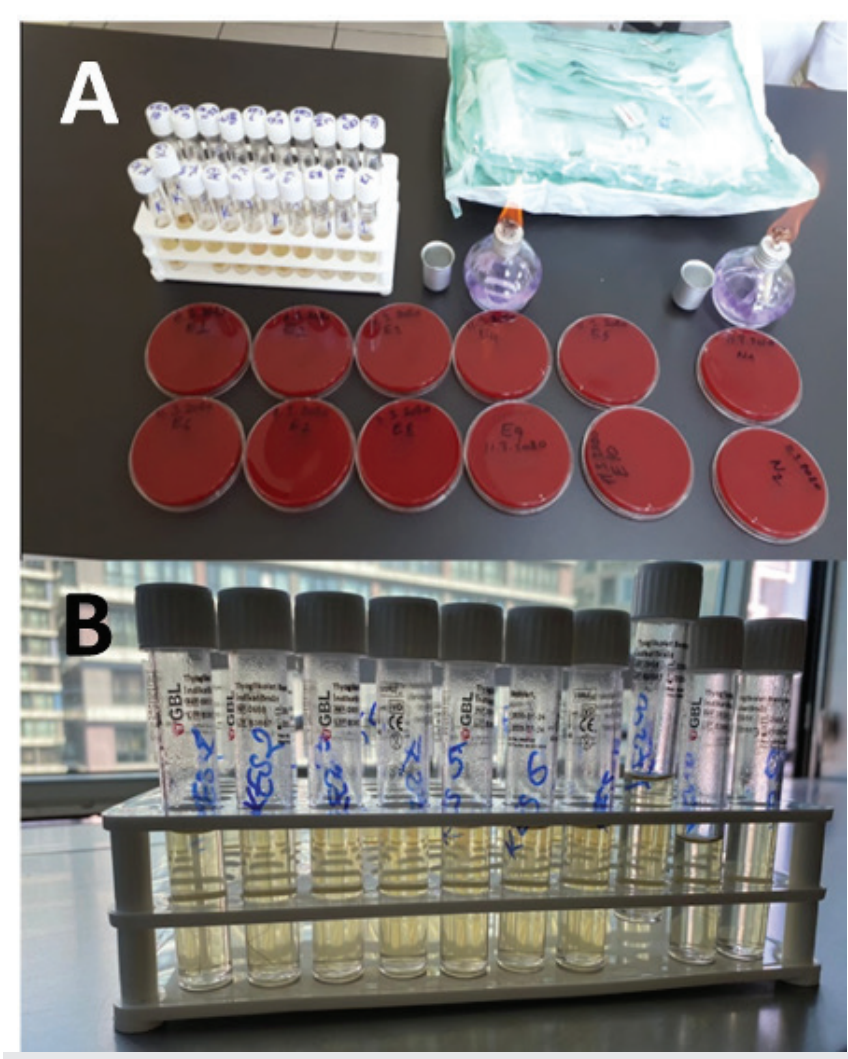

Figure 2. A) Cultivated blood agar mediums. B) Cultivated thioglycolate mediums

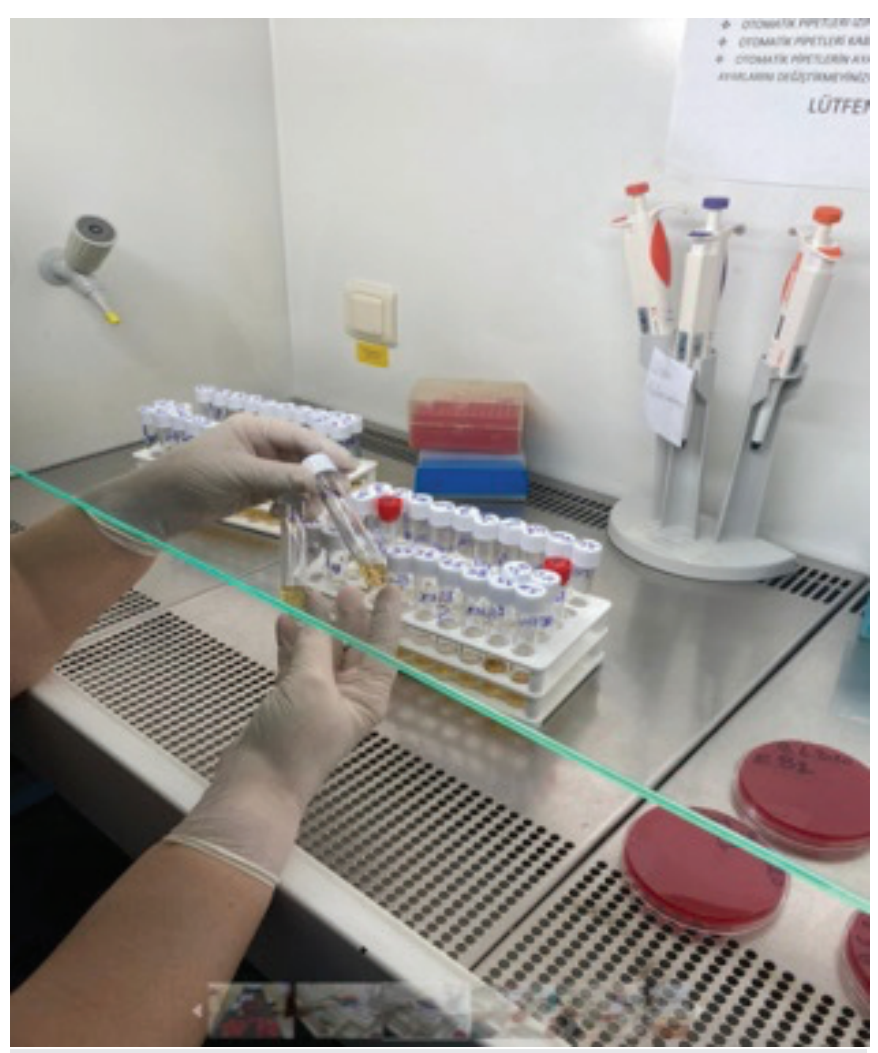

Figure 3. Plating of the hair samples to the blood agar and thioglycolate media in the laminar flow cabinet
Company, rrf. no: 0658) which is a general-purpose medium used for the cultivation of anaerobes and microaerophiles and recommended for tests of biologic materials. This process was performed in a laminar flow cabinet (Figure 3). Incubation was performed for $24-48$ hours at $37{ }^{\circ} \mathrm{C}$ in aerobic incubator. The growth in all mediums was evaluated after 24 and 48 hours (Figure 4) (11).

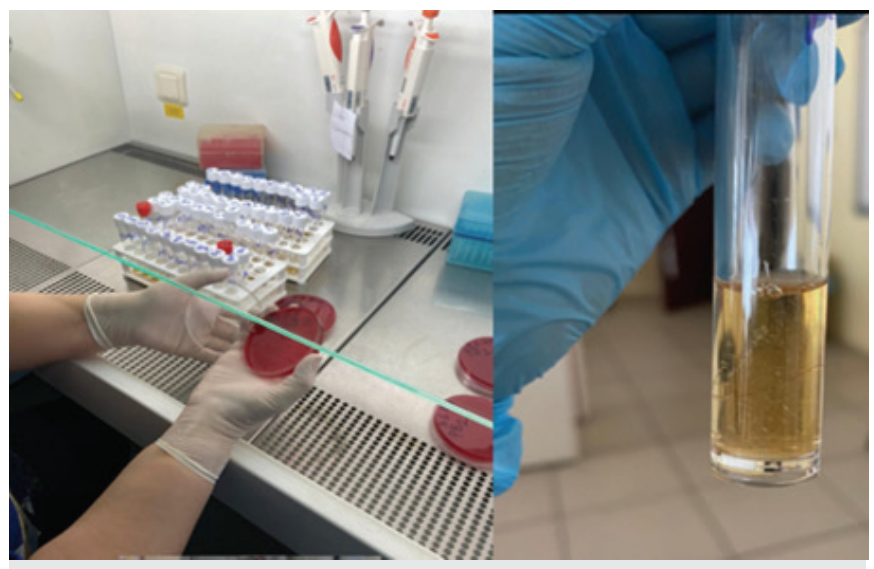

Figure 4. Growth evaluation of plated samples on the blood agar and thioglycolate media in the laminar flow cabinet

\section{Statistical Analysis}

Statistical analysis was not required as no growth was detected in all sterilization methods and packages.

\section{RESULTS}

Evaluations of the cultivation of the swab cultures in the experimental groups and control group on the blood agar medium after 24 and 48 hours revealed no growth. Moreover, observations after 24 and 48 hours of thioglycolate broth cultivation of the hair strands in the experimental groups 1 and 2 showed no growth (Table 1).

\section{DISCUSSION}

Presence of a hair strand in the sterile set is considered to ruin the sterilization by increasing the biological load $(9,10)$. Surgical instruments are considered crucial materials since they penetrate the sterile tissue. Critical materials should be sterile while in use to prevent the risk of infection (12).

Rutala et al. (12), in their study to evaluate the microbial load on surgical instruments before sterilization, showed that the microbial load on surgical instruments after standard cleaning was low. It has been reported that $72 \%$ of devices had 0-10 colony-forming units (CFUs), and only $4 \%$ exceeded 425 CFUs. Furthermore, it has been reported that clean, clean contaminated, contaminated, or dirty nature of operations does not significantly affect microbial load (12). Even if the washing process is applied on the instruments kept without using any sterilization method, there may be microbial load; it should be regarded as non-sterile 
Table 1. Surgical instrument microbiological swab and hair cultivation results

\begin{tabular}{|c|c|c|c|c|c|c|c|c|c|c|c|c|c|c|c|c|c|c|}
\hline \multirow{3}{*}{ Pack No. } & \multicolumn{6}{|c|}{ Autoclave sterilization } & \multicolumn{6}{|c|}{ Hydrogen peroxide sterilization } & \multicolumn{6}{|c|}{ Ethylene oxide sterilization } \\
\hline & \multicolumn{2}{|c|}{$\begin{array}{l}\text { Control } \\
\text { group }\end{array}$} & \multicolumn{2}{|c|}{$\begin{array}{l}\text { Experimental } \\
\text { group } 1\end{array}$} & \multicolumn{2}{|c|}{$\begin{array}{l}\text { Experimental } \\
\text { group } 2\end{array}$} & \multicolumn{2}{|c|}{$\begin{array}{l}\text { Control } \\
\text { group }\end{array}$} & \multicolumn{2}{|c|}{$\begin{array}{l}\text { Experimental } \\
\text { group } 1\end{array}$} & \multicolumn{2}{|c|}{$\begin{array}{l}\text { Experimental } \\
\text { group } 2\end{array}$} & \multicolumn{2}{|c|}{$\begin{array}{l}\text { Control } \\
\text { group }\end{array}$} & \multicolumn{2}{|c|}{$\begin{array}{l}\text { Experimental } \\
\text { group } 1\end{array}$} & \multicolumn{2}{|c|}{$\begin{array}{l}\text { Experimental } \\
\text { group } 2\end{array}$} \\
\hline & 24 & 48 & 24 & 48 & 24 & 48 & 24 & 48 & 24 & 48 & 24 & 48 & 24 & 48 & 24 & 48 & 24 & 48 \\
\hline 101 & $\mathrm{~N}$ & $\mathrm{~N}$ & & & & & N & $\mathrm{N}$ & & & & & $\mathrm{N}$ & $\mathrm{N}$ & & & & \\
\hline 102 & $\mathrm{~N}$ & $\mathrm{~N}$ & & & & & N & $\mathrm{N}$ & & & & & $\mathrm{N}$ & $\mathrm{N}$ & & & & \\
\hline 103 & $\mathrm{~N}$ & $\mathrm{~N}$ & & & & & N & $\mathrm{N}$ & & & & & $\mathrm{N}$ & $\mathrm{N}$ & & & & \\
\hline 104 & $\mathrm{~N}$ & $\mathrm{~N}$ & & & & & N & $\mathrm{N}$ & & & & & $\mathrm{N}$ & $\mathrm{N}$ & & & & \\
\hline 105 & $\mathrm{~N}$ & $\mathrm{~N}$ & & & & & N & $\mathrm{N}$ & & & & & $\mathrm{N}$ & $\mathrm{N}$ & & & & \\
\hline 106 & $\mathrm{~N}$ & $\mathrm{~N}$ & & & & & N & $\mathrm{N}$ & & & & & $N$ & $\mathrm{~N}$ & & & & \\
\hline 107 & $\mathrm{~N}$ & $\mathrm{~N}$ & & & & & $N$ & $\mathrm{~N}$ & & & & & $N$ & $\mathrm{~N}$ & & & & \\
\hline 108 & $\mathrm{~N}$ & $N$ & & & & & $N$ & $\mathrm{~N}$ & & & & & $\mathrm{~N}$ & $\mathrm{~N}$ & & & & \\
\hline 109 & $\mathrm{~N}$ & $N$ & & & & & $N$ & $\mathrm{~N}$ & & & & & $N$ & $N$ & & & & \\
\hline IO 10 & $\mathrm{~N}$ & $N$ & & & & & $N$ & $\mathrm{~N}$ & & & & & $\mathrm{~N}$ & $\mathrm{~N}$ & & & & \\
\hline IO 11 & $\mathrm{~N}$ & $\mathrm{~N}$ & & & & & $N$ & $\mathrm{~N}$ & & & & & $N$ & $\mathrm{~N}$ & & & & \\
\hline IO 12 & $\mathrm{~N}$ & $N$ & & & & & $N$ & $\mathrm{~N}$ & & & & & $\mathrm{~N}$ & $N$ & & & & \\
\hline $\mathrm{FH} 1$ & $\mathrm{~N}$ & $N$ & $N$ & $\mathrm{~N}$ & & & $N$ & $\mathrm{~N}$ & $\mathrm{~N}$ & $\mathrm{~N}$ & & & $N$ & $\mathrm{~N}$ & $\mathrm{~N}$ & $\mathrm{~N}$ & & \\
\hline $\mathrm{FH} 2$ & $\mathrm{~N}$ & $\mathrm{~N}$ & $N$ & $\mathrm{~N}$ & & & $N$ & $\mathrm{~N}$ & $\mathrm{~N}$ & $\mathrm{~N}$ & & & $\mathrm{~N}$ & $\mathrm{~N}$ & $\mathrm{~N}$ & $\mathrm{~N}$ & & \\
\hline $\mathrm{FH} 3$ & $\mathrm{~N}$ & $\mathrm{~N}$ & $N$ & $\mathrm{~N}$ & & & $N$ & $\mathrm{~N}$ & $\mathrm{~N}$ & $\mathrm{~N}$ & & & $N$ & $\mathrm{~N}$ & $\mathrm{~N}$ & $\mathrm{~N}$ & & \\
\hline $\mathrm{FH} 4$ & $\mathrm{~N}$ & $\mathrm{~N}$ & $N$ & $\mathrm{~N}$ & & & $N$ & $\mathrm{~N}$ & $\mathrm{~N}$ & $\mathrm{~N}$ & & & $\mathrm{~N}$ & $N$ & $\mathrm{~N}$ & $\mathrm{~N}$ & & \\
\hline FH 5 & $N$ & $\mathrm{~N}$ & $N$ & $\mathrm{~N}$ & & & $N$ & $\mathrm{~N}$ & $\mathrm{~N}$ & $\mathrm{~N}$ & & & $N$ & $N$ & $\mathrm{~N}$ & $\mathrm{~N}$ & & \\
\hline $\mathrm{FH} 6$ & $\mathrm{~N}$ & $\mathrm{~N}$ & $N$ & $\mathrm{~N}$ & & & $N$ & $\mathrm{~N}$ & $\mathrm{~N}$ & $\mathrm{~N}$ & & & $N$ & $N$ & $\mathrm{~N}$ & $\mathrm{~N}$ & & \\
\hline $\mathrm{FH} 7$ & $\mathrm{~N}$ & $\mathrm{~N}$ & $N$ & $\mathrm{~N}$ & & & $N$ & $\mathrm{~N}$ & $\mathrm{~N}$ & $\mathrm{~N}$ & & & $\mathrm{~N}$ & $\mathrm{~N}$ & $\mathrm{~N}$ & $\mathrm{~N}$ & & \\
\hline FH 8 & $\mathrm{~N}$ & $N$ & $N$ & $\mathrm{~N}$ & & & $N$ & $\mathrm{~N}$ & $\mathrm{~N}$ & $\mathrm{~N}$ & & & $\mathrm{~N}$ & $N$ & $N$ & $\mathrm{~N}$ & & \\
\hline FH 9 & $\mathrm{~N}$ & $\mathrm{~N}$ & $\mathrm{~N}$ & $\mathrm{~N}$ & & & $N$ & $\mathrm{~N}$ & $\mathrm{~N}$ & $\mathrm{~N}$ & & & $\mathrm{~N}$ & $\mathrm{~N}$ & $\mathrm{~N}$ & $\mathrm{~N}$ & & \\
\hline $\mathrm{FH} 10$ & $\mathrm{~N}$ & $\mathrm{~N}$ & $N$ & $\mathrm{~N}$ & & & $N$ & $\mathrm{~N}$ & $\mathrm{~N}$ & $\mathrm{~N}$ & & & $N$ & $\mathrm{~N}$ & $\mathrm{~N}$ & $\mathrm{~N}$ & & \\
\hline $\mathrm{FH} 11$ & $\mathrm{~N}$ & $\mathrm{~N}$ & $N$ & $\mathrm{~N}$ & & & $N$ & $\mathrm{~N}$ & $\mathrm{~N}$ & $\mathrm{~N}$ & & & $\mathrm{~N}$ & $\mathrm{~N}$ & $\mathrm{~N}$ & $\mathrm{~N}$ & & \\
\hline $\mathrm{FH} 12$ & $\mathrm{~N}$ & $\mathrm{~N}$ & $\mathrm{~N}$ & $\mathrm{~N}$ & & & $N$ & $\mathrm{~N}$ & $\mathrm{~N}$ & $\mathrm{~N}$ & & & $\mathrm{~N}$ & $\mathrm{~N}$ & $\mathrm{~N}$ & $\mathrm{~N}$ & & \\
\hline SH 1 & $\mathrm{~N}$ & $\mathrm{~N}$ & & & $\mathrm{~N}$ & $\mathrm{~N}$ & $\mathrm{~N}$ & $\mathrm{~N}$ & & & $N$ & $\mathrm{~N}$ & $N$ & $\mathrm{~N}$ & & & $N$ & $\mathrm{~N}$ \\
\hline SH 2 & $\mathrm{~N}$ & $\mathrm{~N}$ & & & $\mathrm{~N}$ & $\mathrm{~N}$ & $\mathrm{~N}$ & $\mathrm{~N}$ & & & $N$ & $\mathrm{~N}$ & $\mathrm{~N}$ & $\mathrm{~N}$ & & & $\mathrm{~N}$ & $\mathrm{~N}$ \\
\hline SH 3 & $\mathrm{~N}$ & $\mathrm{~N}$ & & & $N$ & $\mathrm{~N}$ & N & $\mathrm{N}$ & & & $N$ & $\mathrm{~N}$ & $\mathrm{~N}$ & $\mathrm{~N}$ & & & $\mathrm{~N}$ & $\mathrm{~N}$ \\
\hline SH 4 & $\mathrm{~N}$ & $\mathrm{~N}$ & & & $\mathrm{~N}$ & $\mathrm{~N}$ & $N$ & $\mathrm{~N}$ & & & $N$ & $\mathrm{~N}$ & $\mathrm{~N}$ & $\mathrm{~N}$ & & & $\mathrm{~N}$ & $\mathrm{~N}$ \\
\hline SH 5 & $\mathrm{~N}$ & $\mathrm{~N}$ & & & $\mathrm{~N}$ & $\mathrm{~N}$ & $N$ & $\mathrm{~N}$ & & & $N$ & $\mathrm{~N}$ & $N$ & $\mathrm{~N}$ & & & $\mathrm{~N}$ & $\mathrm{~N}$ \\
\hline SH 6 & $\mathrm{~N}$ & $\mathrm{~N}$ & & & $\mathrm{~N}$ & $\mathrm{~N}$ & N & $\mathrm{N}$ & & & $N$ & $\mathrm{~N}$ & $\mathrm{~N}$ & $\mathrm{~N}$ & & & $\mathrm{~N}$ & $\mathrm{~N}$ \\
\hline SH 7 & $\mathrm{~N}$ & $\mathrm{~N}$ & & & $\mathrm{~N}$ & $\mathrm{~N}$ & N & $\mathrm{N}$ & & & $N$ & $\mathrm{~N}$ & $\mathrm{~N}$ & $\mathrm{~N}$ & & & $\mathrm{~N}$ & $\mathrm{~N}$ \\
\hline SH 8 & $\mathrm{~N}$ & $N$ & & & $\mathrm{~N}$ & $\mathrm{~N}$ & $N$ & $\mathrm{~N}$ & & & $N$ & $\mathrm{~N}$ & $\mathrm{~N}$ & $\mathrm{~N}$ & & & $\mathrm{~N}$ & $\mathrm{~N}$ \\
\hline SH 9 & $\mathrm{~N}$ & $\mathrm{~N}$ & & & $\mathrm{~N}$ & $\mathrm{~N}$ & $\mathrm{~N}$ & $\mathrm{~N}$ & & & $\mathrm{~N}$ & $\mathrm{~N}$ & $\mathrm{~N}$ & $\mathrm{~N}$ & & & $\mathrm{~N}$ & $\mathrm{~N}$ \\
\hline SH 10 & $\mathrm{~N}$ & $\mathrm{~N}$ & & & $\mathrm{~N}$ & $\mathrm{~N}$ & $N$ & $\mathrm{~N}$ & & & $N$ & $\mathrm{~N}$ & $\mathrm{~N}$ & $\mathrm{~N}$ & & & $\mathrm{~N}$ & $\mathrm{~N}$ \\
\hline SH 11 & $\mathrm{~N}$ & $\mathrm{~N}$ & & & $\mathrm{~N}$ & $\mathrm{~N}$ & $N$ & $\mathrm{~N}$ & & & $\mathrm{~N}$ & $\mathrm{~N}$ & $\mathrm{~N}$ & $\mathrm{~N}$ & & & $\mathrm{~N}$ & $\mathrm{~N}$ \\
\hline SH 12 & $\mathrm{~N}$ & $\mathrm{~N}$ & & & $\mathrm{~N}$ & $\mathrm{~N}$ & $N$ & $\mathrm{~N}$ & & & $N$ & $\mathrm{~N}$ & $\mathrm{~N}$ & $\mathrm{~N}$ & & & $\mathrm{~N}$ & $\mathrm{~N}$ \\
\hline
\end{tabular}

IO: packages including instruments only without a hair strand, $\mathrm{FH}$ : packages including a free hair strand, SH: packages including a hair strand strangulated to the instrument, N: negative

and must be subjected to a sterilization process before use. In this study, all surgical instruments were washed in a washing device at programme 1 at $60^{\circ} \mathrm{C}$ for 22 minutes, passing through the stages of washing, initial rinsing 1 and second rinsing. Microbiological load assessment was not performed before sterilization; hence, all instruments were considered non-sterile.

In this study, paper + film packaging method was used and surgical instruments were placed in individual packages. The packs that 
contained instrument only were used as the control group and the packs containing a hair strand, free or strangulated, were the study groups that contained biologic load. Resendiz et al. (13) studied the risk of bacterial survival and contamination in surgical instruments in the presence of dried blood inoculation. Although it was not statistically significant, wrapped sets were found to be in higher risk of bacterial reproduction in presence of blood (13). Additionally, in this study, it was clearly shown that steam sterilization remains inadequate in the presence of biological debris and contaminated instruments that cause a risk for other clean instruments in the set as well. In this study, a hair strand was used as biological burden and unlike blood residue, it did not cause a higher risk of contamination.

Regardless of the sterilization method, with the presence of hair in the sterile package, especially in cases with no alternative sets, the surgery needs to be cancelled. Karahan et al. (14) reported that $14 \%$ of the delays or cancellations of surgical operations was due to operating room problems. Moreover, they found the mean continuous anxiety scores of the patients who had delayed surgery as significantly higher (45.28 \pm 5.67$)(14)$.

In their letter, Gillespie et al. (15) reported that their operation was cancelled due to a $7 \mathrm{~cm}$ hair strand found in the surgical set opened in the operative table preparation at Southern Health Hospital. It was stated that this cancelled surgery caused an additional cost of 5,000 Australian Dollars and increased surgical stress for the patient, since there were no spare surgical instruments. Although the recommendations of The Australian College of Operating Room Nurses (16) were followed, an experimental study was conducted due to the material and moral damages mentioned. For this purpose, two $5 \mathrm{~cm}$ hair strands, two $5 \mathrm{~cm}$ nylon sutures, and two $5 \mathrm{~cm}$ silk sutures were first dipped in $0.5 \mathrm{McF}$ arland $\left(10^{8}\right.$ CFUs per millilitre) Staphylococcus aureus (ATCC 25923) solution, and each sample was inoculated in tryptic soy broth at $35{ }^{\circ} \mathrm{C}$ without sterilization as the control group. The other half of samples were left in the surgical set as the experimental group, and the sterilization of the surgical set was achieved in the pre-vacuum steam steriliser. Growth was detected within 24 hours in each of the sample cultivated in the control group. In the experimental group, all samples were cultivated in tryptic soy broth at $35{ }^{\circ} \mathrm{C}$ under aseptic conditions after sterilization, and no growth was reported in the control group after 24 and 48 hours and 1 week. The results of this study supported that the use of the surgical instruments in the presence of a hair strand may be possible in cases where cancellation of the surgery carries a high risk (e.g. when there is no spare surgical set); however, these results should be supported with comparative studies on larger sample groups. The results of our study supported the conclusion of Gillespie's study.

No growth was observed from the samples taken from the instruments or the hair in any of the groups for all of the techniques used in our study. Thus, current practices should be revised in the light of the results obtained from our study.
This study was conducted using single instruments in paper and film packages. Multiple instruments in large containers should be tested in further studies before applying the principle in daily practice. Nonetheless, the results in this study are thought to be guiding.

In our study, no statistically significant growth was observed in any of the groups sterilised with all three methods which are the most commonly used ones in our country.

\section{Study Limitations}

The limitations of the study are that surgical instruments are not packaged as a set and that a single surgical instrument is packaged in a double-layer package and subjected to sterilization.

\section{CONCLUSION}

The presence of hair, free or strangulated in the instrument, in the sterile package has no effect on bacterial contamination risk. Further experiments are warranted to explore the effect on larger surgical sets before clinical application.

Ethics Committee Approval: The experimental protocol for the study was approved by the İstanbul Yeni Yüzyıl University, Local Ethics Committee (approval number: 2020/06-453, approval date: 08.06.2020).

Informed Consent: Patient consent was waived.

Peer-review: Externally peer-reviewed.

Author Contributions: Surgical and Medical Practices - N.A., H.B.K., A.D., F.A.; Concept - N.A., S.Y., H.B.K., A.D.; Design - N.A., A.C., H.B.K., S.G., A.D.; Data Collection and/or Processing - N.A., S.Y., A.C., H.B.K., A.D., F.A.; Analysis and/or Interpretation - N.A., S.Y., A.C., H.B.K., S.G., A.D.; Literature Search - N.A., H.B.K., S.G., A.D.; Writing - N.A., S.Y., A.C., H.B.K., S.G., A.D., F.A.

Conflict of Interest: The authors have no conflict of interest to declare.

Financial Disclosure: The authors declared that this study has received no financial support.

\section{REFERENCES}

1. Genç M, Eti Aslan F. Sterilizasyon döngüsünde vazgeçilmez adımlardan birisi; paketleme. 5. Ulusal Sterilizasyon Dezenfeksiyon Kongresi. 4-8 Nisan 2007, Antalya, Türkiye, 195-208.

2. Güven R. Dezenfeksiyon ve sterilizasyon uygulamalarında hasta güvenliği kavramı. 5. Ulusal Sterilizasyon Dezenfeksiyon Kongresi: 4-8 Nisan 2007, Antalya, Türkiye, 411-22.

3. Kapıkıran G, Bülbüloğlu S, Eti Aslan F. Patient safety, patient safety culture, medical errors and adverse events: Review. J Health Nurs Manag 2018; 5: 132-40.

4. Panta G, Richardson AK, Shaw IC. Effectiveness of autoclaving in sterilizing reusable medical devices in healthcare facilities. J Infect Dev Ctries 2019; 13: 858-64.

5. Babuşçu S. Merkezi sterilizasyon ünitesi organizasyonu ve yönetimi. İçinde: Adaş GT, Katran HB, (editörler). A'dan z'ye ameliyathane. İstanbul: Nobel Tıp Kitabevi; 2019. p. 125-76.

6. Perçin D. Sterilization practices and hospital infections: is there a relationship? Int J Antisep Disinfect Steril 2016; 1: 19-22.

7. Walsh SE, Maillard JY. Principles of sterilization. In: Aulton ME, Taylor KMG, (eds). Aulton's pharmaceutics: the design and manufacture of medicines. $5^{\text {th }}$ ed. China: Elsevier; 2017. p. 268-77.

8. Genç Koyucu R. Ameliyathane ekibi görev ve sorumlulukları. İçinde: Adaş GT, Katran HB, (editörler). A'dan z'ye ameliyathane. İstanbul: Nobel Tıp Kitabevi; 2019. p. 177-86. 
9. Soylu T. (2005). Sterilizasyon Kontrolü. 4. Ulusal Sterilizasyon Dezenfeksiyon Kongresi, Samsun, Türkiye, 4. Sterilizasyon Dezenfeksiyon Kongresi Kongre Kitabı, Eds: Günaydın M., Saniç A., Gürler B. p.87-98.

10. Disinfection, Antisepsis, Sterilization Society (DASS). Guide for Disinfection Antisepsis Sterilization. 2019. Last Accessed Date: 07.07.2020. Available from: https://www.das.org.tr/kitaplar/DASRehber2019V10.pdf

11. Bilgehan H. Klinik mikrobiyolojik tanı. Besiyerleri, ekim ve külür yöntemleri. 5.basım. İzmir: Barış Yayınları; 2009: 97-130,703.

12. Rutala WA, Gergen MF, Jones JF, Weber DJ. Levels of microbial contamination on surgical instruments. Am J Infect Control 1998; 26: 143-5.
13. Resendiz M, Horseman TS, Hover AJ, Bradley DF, Lustik MB, West GF. Assessment of surgical instrument bioburden after steam sterilization: a pilot study. Am J Infect Control 2020; 48: 219-21.

14. Karahan E, Çelik S, Zaman F. The reasons for cancellatıon of electıve surgıcal interventions and its effect on patient anxiety level. Celal Bayar University Journal of Science 2020; 7: 123-9.

15. Gillespie E, Othman N, Kotsanas D. When a single hair or suture has been through the sterilization process, is it sterile? Am J Infect Control 2013; 41: 754-5.

16. The Australian College of Operating Room Nurses. ACORN standards for perioperative nursing. Adelaide, South Australia: The Australian College of Operating Room Nurses Ltd; 2008. 